\title{
BIOLOGICAL CHARACTERISTICS OF EUROPEAN PERCH (Perca fluviatilis L., 1758) INHABITING LAKE LADIK (SAMSUN, TURKEY)
}

\author{
Semra Saygin ${ }^{1, *}$, Savas Yilmaz ${ }^{1}$ Okan Yazicioglu², Nazmi Polat ${ }^{1}$
}

${ }^{1}$ Ondokuz Mayis University, Faculty of Arts and Sciences, Biology Department, Samsun-Turkey

${ }^{2}$ Ahi Evran University, Technical Vocational Schools of Higher Education, Botanic and Animal Production Department, Organic Farming Programme, Kırşehir, Turkey

*Corresponding Author, Email: semra.saygin@omu.edu.tr

\section{ARTICLE INFO}

Received: 2 March 2016

Received in revised form: 24 June 2016

Accepted: 1 September 2016

Available online: 10 October 2016

\section{ABSTRACT}

The aim of this study was to determine the growth features of European perch (Perca fluviatilis L., 1758) inhabiting Lake Ladik. A total of 858 individuals were caught. The total length and weight ranged from 8.2 to $27.5 \mathrm{~cm}$ and from 7.16 to $365.20 \mathrm{~g}$, respectively. The age of the females ranged between 1 and 7 years and the age of the males ranged from 1 to 5 years. The female to male ratio was $1: 0.19$. The von Bertalanffy growth equation parameters were determined as $L_{\infty}=41.27 \mathrm{~cm}, W_{\infty}=1251.40 \mathrm{~g}$, $K=0.10$ (year $\left.{ }^{-1}\right), t_{o}$ (year)=-1.98 for all samples. Length-weight relationship was calculated as $W=0.0047 T L^{3.358}$ for all specimens. Length-length relationships (total length-standard length, total length-fork length, standard length- fork length) were highly significant $\left(r^{2}>0.98\right)$. The mean condition factor value was obtained as 1.28 for all fish. Condition factor showed statistically significant increase according to length classes.

Saygin, S., Yilmaz, S., Yazicioglu, O., Polat, N. (2016): Biological characteristics of European perch (Perca fluviatilis L., 1758) inhabiting Lake Ladik (Samsun, Turkey). Croatian Journal of Fisheries, 74, 141-148. DOI: $10.1515 /$ cjf-2016-0022.

\section{INTRODUCTION}

European perch is the most common and widely distributed member of the perch family, and is important both commercially and for sport fishing. It is widespread throughout Europe and Asia and has been successfully introduced in other parts of the world, mainly South Africa, Australia and New Zealand (Thorpe, 1977). European perch is one of the economically important freshwater fishes inhabiting Lake Ladik (Yilmaz et al., 2013).

Biological features of fish should be well-known in fishing and aquaculture research as well as in research about population dynamics and fish biology. There are studies about growth, reproduction, diet and otolith morphometry of European perch (Copp and Kováč, 2003; Polat et al., 2004; Ilhan et al., 2009; Begburs, 2010; Čech et al., 2010; Ceccuzzi et al., 2011; Giannetto et al., 2012; Sabetian et al., 2014; Yilmaz et al., 2014; Banda, 2015; Komsari et al., 2015; Tamás et al., 2015). However, there are no studies about growth characteristics of European perch inhabiting Lake Ladik. Growth features of bream Abramis brama (Erbaşaran 2012), northern pike Esox lucius (Yazıcıoğlu 2014), rudd Scardinius erythrophthalmus (Yazici et al. 2015) were determined in Lake Ladik. Although European perch is a predator fish species, it is an important prey for the top predator northern pike inhabiting Lake Ladik. 
Growth features of European perch should be investigated extensively since it is an economically important species which is invasive for some waters and it holds an important place in the food chain. Therefore, the present work is focused on the growth properties of European perch living in this lake.

\section{MATERIALS AND METHODS}

Lake Ladik $\left(35^{\circ} 40^{\prime}-36^{\circ} 05^{\prime} \mathrm{E}-40^{\circ} 50^{\prime}-41^{\circ} 00^{\prime} \mathrm{N}\right.$ ) is one of the few lakes with floating islands in the world. The lake has a length of $5 \mathrm{~km}$, width of $2 \mathrm{~km}$, depth of 2.5-6 m and altitude of $867 \mathrm{~m}$. This lake, which is a wetland with eutrophic character, has a surface area of $10 \mathrm{~km}^{2}$ (Yilmaz et al., 2013). The sampling was carried out monthly between November 2009 and October 2010 in different parts of Lake Ladik, using gillnets with meshes of $25 \times 25$, $30 \times 30,35 \times 35,40 \times 40 \mathrm{~mm}, 100 \mathrm{~m}$ long and $20 \times 20 \mathrm{~mm}$ $50 \mathrm{~m}$ long. Networks were left in the lake during evening hours and collected the next morning (about 12 hours of exposition). Total length $(T L, \pm 0.1 \mathrm{~cm})$ and weight ( $W$, $\pm 0.01 \mathrm{~g}$ ) of each specimen were recorded. The ages of European perch inhabiting Lake Ladik were determined by using their vertebrae as reliable bony structures by Saygin et al., 2015. Their sexes were determined with macroscopic examination of gonads. The Chi-square test (Zar, 1999) was used to determine whether the sex ratio was different from the expected 1:1 ratio for the entire sample.

The mean total length and weight values of the females and males were compared with the Mann-Whitney $U$ test $(\alpha=0.05)$ (Zar, 1999). The length and weight frequency distributions according to sexes were also compared with the Kolmogorov-Smirnov Z test ( $\alpha=0.05$ ) (Zar, 1999).

Age-length and age-weight relationships were determined using the growth equations developed by von Bertalanffy (Sparre and Venema, 1998):

$L_{t}=L_{\text {cl }}\left[1-\mathrm{e}^{-K(t-t)}\right]$

$W_{t}=W_{c}\left[1-e^{-K(t-t O)}\right]^{b}$

where $L_{t}$ is the total length at age $t, L_{\infty}$ is the asymptotic length $(\mathrm{cm}), K$ is the coefficient of growth (year $\left.{ }^{1}\right), t$ is age (year), $t_{0}$ is the hypothetical age at length $0, W_{t}$ is the weight at age $(g), W_{\infty}$ is the asymptotic weight $(g), b$ is the regression coefficient in the length-weight relationship (Sparre and Venema, 1998). Parameters of $L_{\infty}, K$ and $t_{0}$ were calculated by the FISAT II software package (Gayalino et al., 2005), and $W_{\infty}$ and $b$ were calculated from the length-weight relationship.

The growth performance index was determined by the equation of Munro and Pauly (1983):

$\Phi^{\prime}=\log (K)+2 \log \left(L_{\infty}\right)$

$\Phi$ 'value was obtained in FISAT II software package (Gayalino et al., 2005).

The length-weight relationship was calculated by the formula (Ricker, 1975):

$W=a T L^{b}$

where $W$ is the body weight $(g), T L$ is the total length $(\mathrm{cm})$, $a$ and $b$ are the parameters of the relationship. Whether the $b$ parameter was different from 3 was tested by the t-test (Zar, 1999). The relationships between different length types (total length-standard length, total lengthfork length, standard length-fork length) were detected using linear regression analysis for the females, males and the entire sample.

Fulton's condition factor was calculated:

$C F=\left(W / L^{3}\right) \times 100$

where $W$ is the fish weight $(g), L$ is the total length $(\mathrm{cm})$ (Ricker, 1975). The difference was tested by the t-test $(\alpha=0.05)$ in terms of condition factor values between females and males.

\section{RESULTS}

\section{Growth}

The total length and weight ranged from 8.2 to $27.5 \mathrm{~cm}$ and from 7.16 to $365.20 \mathrm{~g}$ for the entire population, respectively. When the average values of the total length and weight were compared for the female and male samples, it was found that the difference was statistically significant (Mann-Whitney $\mathrm{U}$ test, $\mathrm{P}<0.001$ ). The female individuals were bigger than the males in terms of both length and weight. The female to male ratio was estimated as 1:0.19 and the sex ratio was different from $1: 1$ ratio $\left(X^{2}=403.005\right.$, $\mathrm{df}=1, \mathrm{P}<0.001$; Table 1.). It was observed that the lengthfrequency distribution (Figure 1, 2) (Kolmogorov-Smirnov test, $\quad Z=5.121, \quad P<0.001)$ and the weight-frequency distribution (Figure 3 and 4) (Kolmogorov-Smirnov test, $\mathrm{Z}=5.280, \mathrm{P}<0.001$ ) were different between females and males.

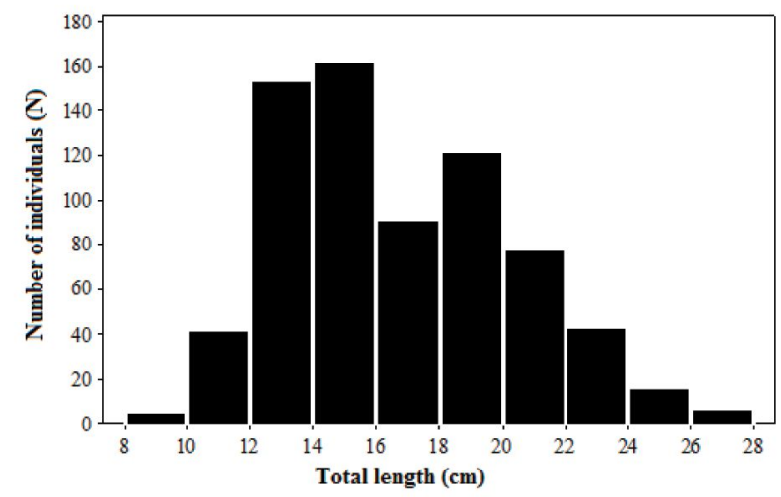

Fig 1. Length-frequency distribution for the females of European perch 


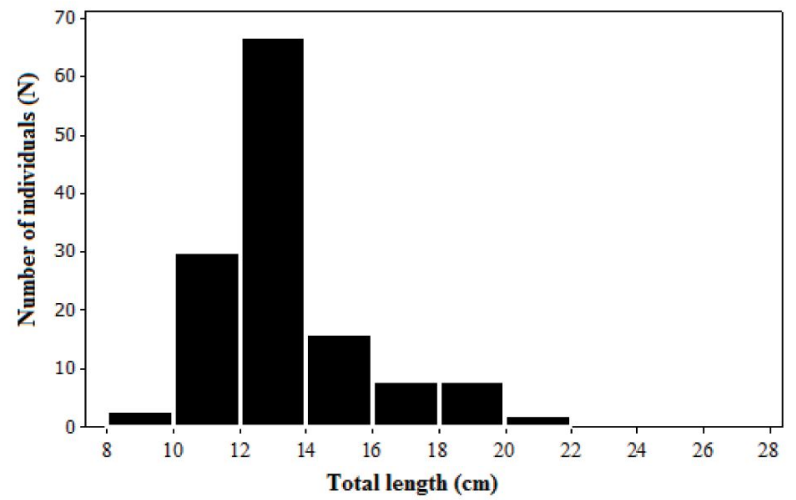

Fig 2. Length-frequency distribution for the males of European perch

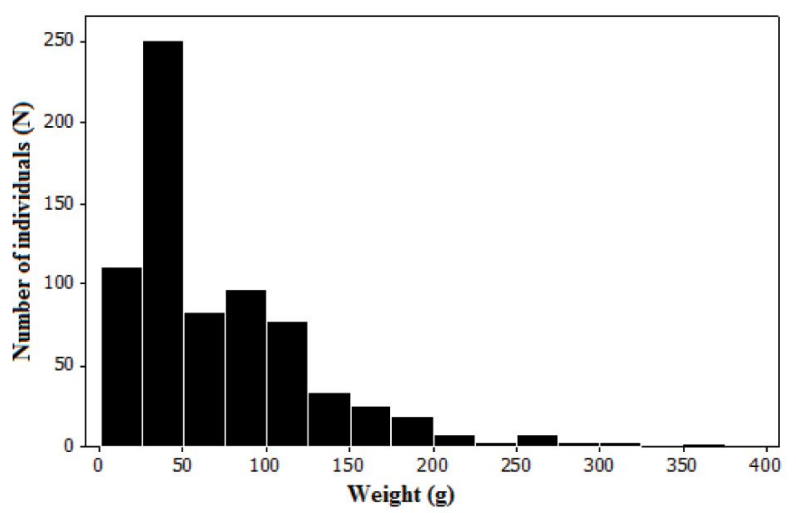

Fig 3. Weight-frequency distribution for the females of European perch

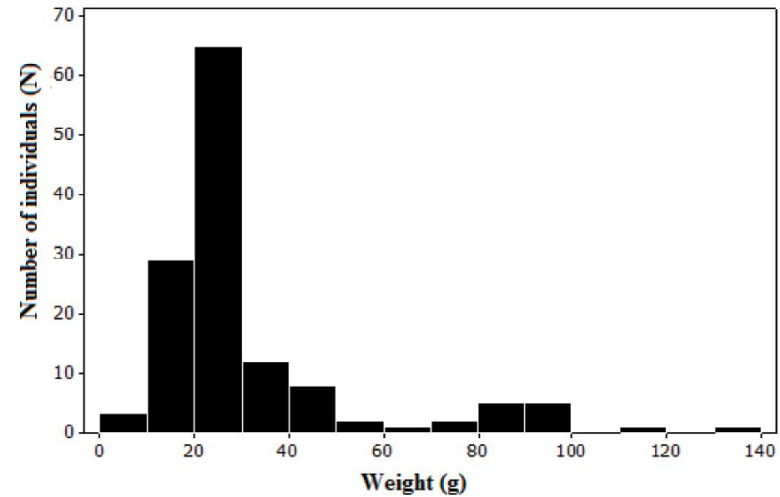

Fig 4. Weight-frequency distribution for the males of European perch

Age ranged from 1-7 years for the females and 1-5 years for the males. The age groups II and III were dominant with the values of $25.52 \%$ and $25.06 \%$, respectively. The mean total length was statistically different between females and males in the same age groups, except for the age group $\mathrm{V}$ ( $t$ - test, $\mathrm{P}<0.05)$. The mean weight was statistically different between females and males for the age groups I-IV (t-test, $\mathrm{P}<0.05$ ).

$L_{\infty}$ was calculated as $43.72 \mathrm{~cm}$ for female, $23.55 \mathrm{~cm}$ for male (Table 2).

\section{Length-weight relationships}

The length-weight relationships were $W=0.0047 \times T L^{3.364}$ for the females and $W=0.0054 \times T L^{3.301}$ for the males. The graph of the length-weight relationship for all individuals is

Table 1. Descriptive statistics of total length and weight of European perch in Lake Ladik

\begin{tabular}{ccccccccccc}
\hline Sex & \multicolumn{4}{c}{ Total Length $(\mathrm{cm})$} & \multicolumn{3}{c}{ Weight (g) } \\
\hline & $\mathrm{N}$ & Mean & Sd & Min & Max & Mean & Sd & Min & Max \\
Female & 721 & 16.61 & 3.65 & 8.5 & 27.5 & 72.02 & 56.36 & 7.16 & 365.20 \\
Male & 134 & 13.35 & 2.32 & 8.7 & 20.6 & 32.04 & 23.45 & 7.74 & 131.08 \\
Undetermined & 3 & 8.47 & 0.23 & 8.2 & 8.6 & 7.38 & 0.25 & 7.22 & 7.67 \\
All & 858 & 16.08 & 3.69 & 8.2 & 27.5 & 65.55 & 54.56 & 7.16 & 365.20 \\
\hline
\end{tabular}

$\mathrm{N}$ : Number of individuals, Sd: Standard deviation, Min: Minimum, Max: Maximum

Table 2. The von Bertalanffy growth parameters and growth performance index values in the length and weight for European perch

\begin{tabular}{lcccccc}
\hline \hline Sex & $L_{\infty}(\mathrm{cm})$ & $W_{\infty}(\mathrm{g})$ & $K\left(\right.$ year $\left.^{-1}\right)$ & $t_{0}$ (year) & $b$ & $\Phi^{\prime}$ \\
\hline Female & 43.72 & 1553.62 & 0.09 & -2.15 & 3.364 & 2.236 \\
Male & 23.55 & 182.53 & 0.18 & -2.26 & 3.301 & 1.999 \\
All & 41.27 & 1251.40 & 0.10 & -1.98 & 3.358 & 2.231 \\
\hline \hline
\end{tabular}


presented in Figure 5 . It was found that all $b$ values were significantly different from 3 ( $t$-test, $P<0.05$ ), and this finding showed that the growth was positively allometric.

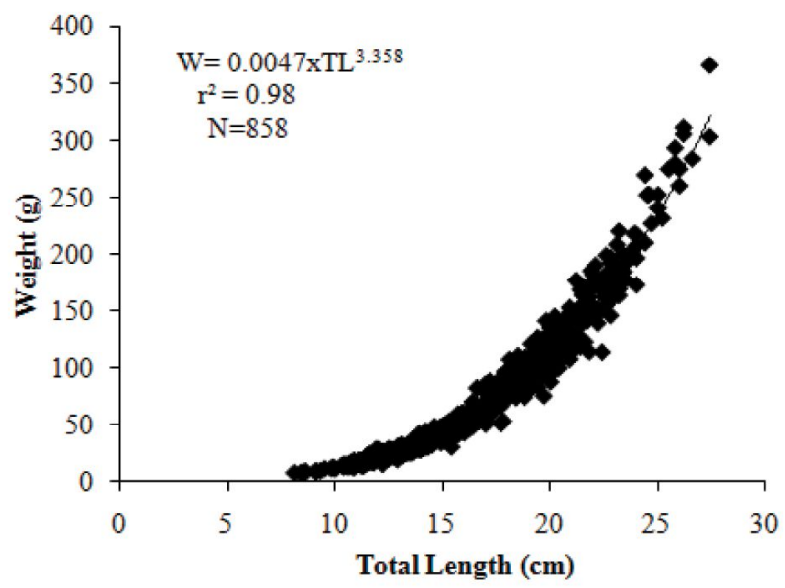

Fig 5. The length-weight relationship of European perch sampled in Lake Ladik (N: number of individuals)

\section{Length-length relationships}

The relationships of the total-fork length, fork-standard length, standard-total length were calculated to reveal length conversions (Table 3.) and it was found that there were strong relationships between different length types $\left(\mathrm{P}<0.001, \mathrm{r}^{2}>0.98\right)$.

\section{Condition factor}

The values of the condition factor for the females, males and all specimens were calculated as 1.30, 1.18 and 1.28 , respectively (Table 4 ). When the condition factors of the females and males in the same age groups were compared, the differences were statistically significant for the age groups II and III (t-test, $\mathrm{P}<0.05)$. Similarly, the condition factors were also different between the females and males in the whole sample (t-test, $\mathrm{P}<0.05$ ). The females had higher condition factors than the males in every comparison that had significant differences.

Table 3. The length-length relationships of European perch

\begin{tabular}{|c|c|c|c|c|c|}
\hline Sex & $\mathrm{N}$ & Equations & $a$ & $b$ & $r^{2}$ \\
\hline & & $T L=a+b F L$ & 0.0037 & 1.06 & 0.99 \\
\hline \multirow[t]{3}{*}{ Female } & 721 & $\mathrm{FL}=\mathrm{a}+\mathrm{b} \mathrm{SL}$ & 0.465 & 1.08 & 0.99 \\
\hline & & $S L=a+b T L$ & -0.315 & 0.87 & 0.99 \\
\hline & & $T L=a+b F L$ & 0.172 & 1.04 & 0.99 \\
\hline \multirow[t]{3}{*}{ Male } & 134 & $\mathrm{FL}=\mathrm{a}+\mathrm{b} \mathrm{SL}$ & 0.308 & 1.09 & 0.99 \\
\hline & & $S L=a+b T L$ & -0.242 & 0.87 & 0.99 \\
\hline & & $\mathrm{TL}=\mathrm{a}+\mathrm{b} \mathrm{FL}$ & 0.0073 & 1.06 & 0.99 \\
\hline \multirow[t]{2}{*}{ All } & 858 & $F L=a+b S L$ & 0.399 & 1.08 & 0.99 \\
\hline & & $S L=a+b T L$ & -0.264 & 0.87 & 0.99 \\
\hline
\end{tabular}

(TL: Total Length, FL: Fork Length, SL: Standard Length)

Table 4. The values of the condition factors for European perch according to age

\begin{tabular}{|c|c|c|c|c|c|c|}
\hline & \multicolumn{2}{|c|}{ Female } & \multicolumn{2}{|c|}{ Male } & \multicolumn{2}{|c|}{ All } \\
\hline Age & $\mathrm{N}$ & $\begin{array}{c}C F \pm S e \\
\text { (Min-Max) }\end{array}$ & $\mathrm{N}$ & $\begin{array}{c}C F \pm S e \\
\text { (Min-Max) }\end{array}$ & $\mathrm{N}$ & $\begin{array}{c}C F \pm S e \\
\text { (Min-Max) }\end{array}$ \\
\hline 1 & 63 & $\begin{array}{c}1.16 \pm 0.01 \\
(0.94-1.37)\end{array}$ & 29 & $\begin{array}{c}1.18 \pm 0.02 \\
(0.91-1.41)\end{array}$ & 95 & $\begin{array}{c}1.17 \pm 0.01 \\
(0.91-1.41)\end{array}$ \\
\hline II & 173 & $\begin{array}{c}1.19 \pm 0.01 \\
(0.80-1.58)\end{array}$ & 46 & $\begin{array}{c}1.14 \pm 0.02 \\
(0.79-1.33)\end{array}$ & 219 & $\begin{array}{c}1.18 \pm 0.01 \\
(0.79-1.58)\end{array}$ \\
\hline III & 176 & $\begin{array}{c}1.24 \pm 0.01 \\
(0.98-1.76)\end{array}$ & 39 & $\begin{array}{c}1.15 \pm 0.02 \\
(0.97-1.58)\end{array}$ & 215 & $\begin{array}{c}1.23 \pm 0.01 \\
(0.97-1.76)\end{array}$ \\
\hline IV & 150 & $\begin{array}{c}1.37 \pm 0.01 \\
(0.90-1.77)\end{array}$ & 16 & $\begin{array}{c}1.37 \pm 0.05 \\
(1.00-1.71)\end{array}$ & 166 & $\begin{array}{c}1.36 \pm 0.01 \\
(0.90-1.77)\end{array}$ \\
\hline V & 114 & $\begin{array}{c}1.42 \pm 0.02 \\
(0.99-1.82)\end{array}$ & 4 & $\begin{array}{c}1.36 \pm 0.11 \\
(1.07-1.56)\end{array}$ & 118 & $\begin{array}{c}1.42 \pm 0.01 \\
(0.99-1.82)\end{array}$ \\
\hline $\mathrm{VI}$ & 31 & $\begin{array}{c}1.47 \pm 0.03 \\
(1.23-1.73)\end{array}$ & - & - & 31 & $\begin{array}{c}1.47 \pm 0.03 \\
(1.23-1.73)\end{array}$ \\
\hline VII & 14 & $\begin{array}{c}1.60 \pm 0.03 \\
(1.46-1.83)\end{array}$ & - & - & 14 & $\begin{array}{c}1.60 \pm 0.03 \\
(1.46-1.83)\end{array}$ \\
\hline All & 721 & $\begin{array}{c}1.30 \pm 0.01 \\
(0.80-1.83)\end{array}$ & 134 & $\begin{array}{c}1.18 \pm 0.01 \\
(0.79-1.71)\end{array}$ & 858 & $\begin{array}{c}1.28 \pm 0.01 \\
(0.79-1.83)\end{array}$ \\
\hline
\end{tabular}




\section{DISCUSSION}

The growth of fish varies widely among water bodies and such growth variations have been linked to both biotic and abiotic factors. The growth of European perch depends on complex interactions with water temperature (Le Cren, 1958; Coble, 1966), pH (Tolonen et al., 2003), population density (Rask, 1983), and food density and availability (Craig, 1978).

Sex ratio of fish varies according to species, among populations of the same species and from year to year in the same population (Nikolsky, 1963). Similar to the results of our study (1:0.19), females were generally more dominant than males in literature (IIhan et al., 2009; Ceccuzzi et al., 2011). The female to male ratio of European perch is calculated as 1:0.25 in Lake Pounui (Jellyman,
1980), 1:0.85 in Tahtalı Dam Lake (Ilhan et al., 2009), 1:0.44 in Lake Varesa (Ceccuzzi et al., 2011) and 1:0.62 in the Curonian Lagoon (Troynikov et al., 2011). Jellyman (1980) stated that the overall dominance of females in the population is principally due to a much higher mortality of males than females between age classes 0 and 1 . This may be due to selective predation on males similar to those recorded by Alm (1959) who considered that the higher activity of males made them more vulnerable to predation. Northern pike, which is a predator species, fed on European perch in Lake Ladik (Yazıcıoğlu, 2014). Also, gonad maturation takes place earlier in males than females.

In this study, maximum total length and weight values were determined as $27.5 \mathrm{~cm}$ and $365.20 \mathrm{~g}$, respectively. The longest perch was sampled from Swedish Lakes

Table 5. The parameters of von Bertalanffy growth equations and the growth performance index in different locations for European perch

\begin{tabular}{|c|c|c|c|c|c|c|c|}
\hline Reference & Habitat & Sex & $L_{\infty}$ & $W_{\infty}$ & $K$ & $t_{0}$ & $\Phi^{\prime}$ \\
\hline \multirow{2}{*}{ Jellyman (1980)** } & \multirow{2}{*}{ Lake Pounui } & Female & 34.80 & $625.43^{b}$ & 0.19 & -2.94 & 2.39 \\
\hline & & Male & 24.80 & $204.46^{b}$ & 0.24 & -2.58 & 2.18 \\
\hline \multirow{3}{*}{ Begburs $(2010)^{* *}$} & \multirow{3}{*}{ Urkmez Dam Lake } & Female & 49.98 & 2872.61 & 0.21 & -0.83 & $2.72^{\mathrm{a}}$ \\
\hline & & Male & 49.62 & 2624.05 & 0.20 & -0.83 & $2.70^{\mathrm{a}}$ \\
\hline & & All & 51.16 & 3013.12 & 0.19 & -0.86 & $2.71^{\mathrm{a}}$ \\
\hline \multirow{3}{*}{ Ceccuzzi et al. (2011)* } & \multirow{3}{*}{ Lake Varese } & Female & 35.52 & $664.31^{\mathrm{b}}$ & 0.18 & -1.71 & 2.37 \\
\hline & & Male & 32.85 & $422.22^{b}$ & 0.20 & -1.56 & 2.34 \\
\hline & & All & 33.17 & - & 0.22 & -1.34 & 2.39 \\
\hline \multirow{5}{*}{$\begin{array}{l}\text { Sabetian et al. } \\
(2014)^{* * *}\end{array}$} & \multirow{3}{*}{$\begin{array}{l}\text { Lake Wainamu } \\
\text { (2012) }\end{array}$} & Female & 15.9 & - & 1.88 & - & - \\
\hline & & Male & 18.6 & - & 1.48 & - & - \\
\hline & & All & 17.9 & - & 1.51 & - & - \\
\hline & \multirow{3}{*}{$\begin{array}{l}\text { Lake Wainamu } \\
\text { (2013) }\end{array}$} & Female & 20.3 & - & 1.36 & - & - \\
\hline & & Male & 25.7 & - & 0.91 & - & - \\
\hline \multirow{7}{*}{ Banda $(2015)^{* * *}$} & & All & 24.5 & - & 0.93 & - & - \\
\hline & \multirow{3}{*}{$\begin{array}{l}\text { Warkworth Quarry } \\
\text { Lake }\end{array}$} & Female & 21.9 & - & 0.18 & - & 1.94 \\
\hline & & Male & 21.3 & - & 0.45 & - & 2.31 \\
\hline & & All & 25.1 & - & 0.24 & -2.24 & 2.18 \\
\hline & \multirow{3}{*}{ Lake Rototoa } & Female & 21.2 & - & 1.75 & - & 2.89 \\
\hline & & Male & 29.4 & - & 0.84 & - & 2.86 \\
\hline & & All & 27.5 & - & 0.98 & -0.08 & 2.86 \\
\hline \multirow{2}{*}{ Komsari et al. (2015)* } & \multirow{2}{*}{ Anzali Wetland } & Female & 21.00 & $120.89^{b}$ & 0.33 & -0.90 & $2.16^{\mathrm{a}}$ \\
\hline & & Male & 21.17 & $141.62^{b}$ & 0.31 & -0.80 & $2.14^{\mathrm{a}}$ \\
\hline \multirow{3}{*}{ This study } & \multirow{3}{*}{ Lake Ladik } & Female & 43.72 & 1553.62 & 0.09 & -2.15 & 2.23 \\
\hline & & Male & 23.55 & 182.53 & 0.18 & -2.26 & 1.99 \\
\hline & & All & 41.27 & 1251.40 & 0.10 & -1.98 & 2.23 \\
\hline
\end{tabular}


with a total length of $49.5 \mathrm{~cm}$ (Holmgren and Appelberg, 2001). The heaviest perch was reported from the lakes of the Aukštaitija National Park with a weight of $2215 \mathrm{~g}$. Kottelat and Freyhof (2007) reported a maximum length of $60 \mathrm{~cm}$ for European perch. According to our results, European perch population was composed of mostly young individuals. This resulted from the fact that the fishing activities in the lake were aimed at larger individuals. The highest age was 7 years and this only confirmed our observations. The smallest individuals were at the age of one and there were no individuals at the age of zero in any sexes. This case was thought to have resulted from the mesh size of fishing nets and predation of northern pike on perch in the lake. In literature, the ages of the fish ranged between 0-17 years. Age of Europeran perch was found to be 0-5 years in Lake Pounui (Jellyman, 1980), 1-7 years in Lake Trasimeno (Lorenzoni et al., 1993) and 0-7 years in Lake Varesa (Ceccuzzi et al., 2011). The maximum age was observed under 7 years at many locations. Besides these researches, the maximum age of European perch was determined to be 2 and 17 years in the Aukštaitija National Park (Balkuvien et al., 2003) and 0 and 17 years in Lake Valkea Kotinen (Afolabi, 2011). It appeared that European perch had extensive age distribution.

In Lake Ladik, similar to the reports for other European perch populations in literature (Jellyman, 1980, Ceccuzzi et al., 2011), males grew faster and lived shorter than females according to the von Bertalanffy parameters (Table 5). In Lake Ladik, the comparison between sexes showed that females were larger than males; furthermore, females had higher $L_{\infty}$ than males. This is probably due to the fact that gonad maturation takes place earlier in males than females; thus, the latter have more time to utilize the energy for somatic growth. Similar results were also obtained from different research (Jellyman, 1980; Heibo and Magnhagen, 2005; Ceccuzzi et al., 2011). The growth performance index calculated in different locations for $P$. fluviatilis was similar. The parameters of length-weight relationship showed that the growth of European perch inhabiting Lake Ladik was positive allometric. The parameters of length-weight relationship found in this study were similar to the results of the researches completed in different locations (Lorenzoni et al., 1993; Begburs, 2010; Ceccuzzi et al., 2011). These parameters of fish may change according to habitat, season, stomach occupancy rate, sex, gonad maturity and length distributions (Wootton, 1998).

In this study, the females have higher condition factors than the males. Condition factor values obtained from different investigations are given in Table 6. Our results showed similarity with those of the Curonian Lagoon (Ložys, 2004), Lake Varesa (Ceccuzzi et al., 2011) and Lithuanian coastal waters of the Baltic Sea populations (Ložys, 2004). The condition factors of fish change according to sex, age composition, habitat, season. Condition factors of P.fluviatilis increased with age in Lake Ladik. The condition factors of fish change also according to measured length types. Standard or total lengths are used to determine condition factors in different research.

Consequently, considering the length-weight distribution, growth parameters, length-weight relationships and condition factors of European perch in the lake, this species shows a good development in Lake Ladik.

This study is the first comprehensive research determining the growth features of European perch inhabiting Lake Ladik. The results obtained from this study may be useful for future research concerned with European perch.

Table 6. The values of the condition factors of European perch in different locations

\begin{tabular}{llcl}
\hline \hline Reference & Habitat & Sex & CF \\
\hline Lorenzoni et al. (1993)** & Lake Trasimeno & Female & 1.68 \\
& Lake Dabie & Male & 1.61 \\
Szypuła (1994)** & Szczecin Lagoon & All & 1.84 \\
Ceccuzzi et al. (2011)* & Lake Varese & All & 2.24 \\
& & Female & 1.24 \\
This study* & & Male & 1.14 \\
& Lake Ladik & Female & 1.30 \\
\hline \hline
\end{tabular}

${ }^{*}$ Total length, ${ }^{*} *$ standard length 


\section{ACKNOWLEDGEMENTS}

This study was financially supported by Ondokuz Mayis University (Project No: PYO. 1901.09.005).

\section{Sadržaj}

\section{BIOLOŠKA OBILJEŽJA GRGEČA (Perca fluviatilis L., 1758) KOJI NASTANJUJE JEZERO LADIK (SAMSUN, TURSKA)}

Cilj ovog istraživanja je utvrditi parametre rasta grgeča (Perca fluviatilis L., 1758) koji nastanjuje jezero Ladik. Ukupno je ulovljeno 858 jedinki. Ukupna dužina i težina su u rasponu od 8,2 do $27,5 \mathrm{~cm}$, odnosno od 7,16 do $365,2 \mathrm{~g}$. Dob ženki kretala se u rasponu od 1 do 7 godina, a dob mužjaka u rasponu od 1 do 5 godina. Odnos ženki i mužjaka bio je 1: 0,19 . Parametri von Bertalanffijeve jednadžbe su određeni kao $L_{\infty}=41,27 \mathrm{~cm}, W_{\infty}=1251,40 \mathrm{~g}, K=0,10\left(\right.$ godina $\left.^{-1}\right), t_{o}$ (godina) $=-1,98$ za sve uzorke. Dužinsko-maseni odnosi su izračunati kao $W=0,0047 \mathrm{TL}^{3,358}$ za sve uzorke. Dužinskodužinski odnosi (totalna dužina-standardna dužina, totalna dužina-dužina vilice, standardna dužina-dužina vilice) bili su veoma značajni $\left(r^{2}>0,98\right)$. Prosječna vrijednost faktora kondicije je utvrđena kao 1,28 za sve ribe. Faktor kondicije ukazuje na statistički značajan porast prema dužinskim razredima.

Ključne riječi: parametri rasta, dužinsko-maseni odnosi, faktor kondicije, dužinsko-dužinski odnosi

\section{REFERENCES}

Afolabi, A.B. (2011): Growth and population structure of perch in relation to diet in a Small Humik Lake, ValkeaKotinen. Jyväskylä (Finland): University of Jyväskylä. 25 pp.

Alm, G. (1959): Connection between maturity, size, and age in fishes. Report of the Institute of Freshwater Research Drottingholm, 40, 5-145.

Balkuvienè, G., Kesminas, V., Virbickas, T. (2003): Fish diversity and growth in Lakes of Aukštaitija National Park. Acta Zoologica Lituanica, 13, 4, 355-371.

Banda, F. (2015): A Comparative analysis of Perca fluviatilis population dynamics from two Lakes in New Zealand. (Auckland) New Zealand: Auckland University of Technology. $98 \mathrm{p}$.

Begburs, C.R. (2010): Investigation of growth features of perch (Perca fluviatilis L. 1758) population in Urkmez Dam Lake (Izmir-Turkey). 2nd International Symposium on Sustainable Develeopment; 2010 June 8-9, Bosnia. Sarajevo, p. 693-699.

Ceccuzzi, P., Terova, G., Brambilla, F., Antonini, M., Saroglia, M. (2011): Growth, diet, and reproduction of European
Perch Perca fluviatilis L. in Lake Varese, Northwestern Italy. Fisheries Science, 77, 4, 533-545.

Čech, M., Peterka, J., Říha, M., Draštik, V., Kratochvíl, M., Kubečka, J. (2010). Deep spawning of perch (Perca fluviatilis, L.) in the newly vreated Chabařovice Lake, Czech Republic. Hydrobiologia, 649, 375-378.

Coble, D.W. (1966): Dependence of total annual growth in yellow perch on temperature. Journal of the Fisheries Research Board of Canada, 23, 1, 15-20.

Copp, H.G., Kovāč, V. (2003). Biometric relationships between body size and bone lengths in fish prey of the Eurasian otter Lutra lutra: chub Leuciscus cephalus and perch Perca fluviatilis. Folia Zool, 52, 1, 109-112.

Craig, J.F. (1978): A study of the food and feeding of perch, Perca fluviatilis L., in Windermere. Freshwater Biology, 8, 1, 59-68.

Erbaşaran, M. (2012): Ladik Gölü (Samsun, Türkiye)'ndeki çapak balığı, Abramis brama (L., 1758)'da yaş belirleme ve büyüme özelliklerinin tespiti. Samsun (Turkey): Ondokuz Mayis Universtiry, 67 p.

Gayanilo, P.C., Spare, P., Pauly, D. (2005): FAO-ICLARM stok assessment tools II (FISAT II) revised version. User's Guide. FAO Computerized Information Series (Fisheries) No:8. Rome, FAO. 168pp.

Giannetto, D., Carosi A., Franchi, E., La Porta, G., Lorenzoni, M. (2012): Proposed standard weight (Ws) equation for European perch (Perca fluviatilis Linnaeus, 1758). Journal of Applied Ichthyology, 28, 34-39.

Heibo, E., Magnhagen, C. (2005): Variation in age and size at maturity in perch (Perca fluviatilis L.), compared across lakes with different predation risk. Ecology of Freshwater Fish, 14, 4, 344-351.

Holmgren, K., Appelberg, M. (2001): Effects of environmental factors on size related growth efficiency of Perch, Perca fluviatilis. Ecology of Freshwater Fish, 10, 2, 247-256.

Ilhan, A., Ustaoğlu, M.R., Sarı, H.M., Başıaçık, S., Gürleyen, N. (2009): Tahtalı Baraj Gölü (İzmir) tatlısu levreği (Perca fluviatilis L.,1758) populasyonunun üreme özellikleri. Ege University Journal of Fisheries \& Aquatic Sciences, 26, 4, 257-260.

Jellyman, D.J. (1980): Age, growth and reproduction of perch, Perca fluviatilis L., in Lake Pounui. New Zealand Journal of Marine and Freshwater Research, 14, 4, 391 400.

Komsari, M.S., Bani, A., Khara, H. (2015): Growth and population structure of the European perch, Perca fluviatilis Linnaeus, 1758 (Osteichthyes: Percidae) in the Anzali Wetland south-west Caspian Sea. Indian Journal of Fisheries, 62, 1, 6-11.

Kottelat, M., Freyhof, J. (2007): Handbook of European freshwater fishes. Cornol, Switzerland. Publications Kottelat. 
Le Cren, E.D. (1958): Observations on the growth of Perch (Perca fluviatilis L.) over twenty-two years with special reference to the effects of temperature and changes in population density. Journal of Animal Ecology, 27, 2, 287-334.

Lorenzoni, M., Giovinazzo, G., Mearelli, M., Natali, M. (1993): Growth and biology of perch (Perca fluviatilis L.) in Lake Trasimeno (Umbria, Italy). Polskie Archiwum Hydrobiologii, 40, 3, 313-328.

Ložys, L. (2004): The growth of pikeperch (Sander lucioperca L.) and perch (Perca fluviatilis L.) under different water temperature and salinity conditions in the Curonian Lagoon and Lithuanian Coastal Waters of The Baltic Sea. Hydrobiologia, 514, 1, 105-113.

Munro, J.L., Pauly, D. (1983): A simple method for comparing growth of fishes and invertebrates. Fishbyte, 1, 1, 5-6.

Nikolsky, G. V. (1963): The ecology of fishes. Academic Press, London and New York, 352 p.

Polat, N., Bostancı, D., Yılmaz, S. (2004): Age analysis on different bony structures of Perch (Perca fluviatilis L. 1758) inhabiting Derbent Dam Lake (Bafra, Samsun). Turkish Journal of Veterinary and Animal Sciences, 28, 465-469.

Rask, M. (1983): Differences in growth of perch (Perca fluviatilis L.) in two small forest lakes. Hydrobiologia, 13, 139-144.

Ricker, W.E. (1975): Computation and interpretation of biological statistics of fish populations. Ottawa: Bulletin. Fisheries Research Board of Canada, 191, 1-382.

Sabetian, A., Trip, E. D. L., Wheeler, P., Sands, L., Wakefield, S., Visconti, V., Banda, F. (2014): Biological plasticity of non-native european perch (Perca fluviatilis) populations and the implications for management in Northern New Zealand. New Zealand Journal of Marine and Freshwater Research, 49, 1, 119-131.

Saygin, S., Yilmaz S., Yazicioglu, O., Polat, N. (2015): Comparative age determination from different bony structures of Perch (Perca fluviatilis Linnaeus, 1758) in Lake Ladik (Samsun/Turkey). Biological Diversity and Conservation, 8, 1, 21-27.

Sparre, P., Venema, S.C. (1998): Introduction to tropical fish stock assessment-Part 1. FAO Fisheries Technical Paper N 306. 1, 377 p.

Szypuła, J. (1994): The growth rate of perch in the firth of Szczecin and Dąbie Lake. Zeszyty Naukowe Akademii Rolniczej w Szczecinie, 164, 21, 73-84.

Tamás, V., Nyeste, K., Papp, G., Antal, L. (2015): New data to growth of Perch (Perca fluviatilis L., 1758). Pisces Hungarici, 9, 39-44.

Thorpe, J.E. (1977): Synopsis of biological data on the perch, Perca fluviatilis Linnaeus, 1758 and Perca flavescens Mitchill, 1804. FAO Fisheries Synopsis No:113. Rome: FAO. 147 pp.

Tolonen, A., Lappalainen, J., Pulliainen, E. (2003): Seasonal growth and year class strength variations of perch near northern limits of its distribution range. Journal of Fish Biology, 63, 1, 176-186.

Troynikov, V.S., Gorfine, H.K., Ložys, L., Pūtys, Z., Jakubavičiūtè, E., Day, R.W. (2011): Parameterization of European perch Perca fluviatilis length-at-age data using stochastic Gompertz growth models. Journal of Fish Biology, 79, 7, 1940-1949.

Wootton, R.J. (1998): Ecology of teleost fishes. 2nd Edition. Chapman \& Hall, London.

Yazici, R., Yilmaz, S., Yazicioglu, O., Polat, N. (2015): Population structure and growth of rudd Scardinius erytrophthalmus (L., 1758) from eutrophic Lake in Northern Anatolia. Croatian Journal of Fisheries, 73, 94-102.

Yazıcıoğlu, O. (2014): Ladik Gölü (Samsun)'ndeki turna balığı (Esox lucius L., 1758)'nın biyolojik özellikleri. Samsun (Turkey): Ondokuz Mayis University. 133 p.

Yilmaz, S., Yazicioglu, O., Saygin (Ayaydin), S., Polat, N. (2014). Relationships of otolith dimensions with body length of European Perch, Perca fluviatilis L., 1758 from Lake Ladik, Turkey. Pakistan J. Zool, 46, 5, 1231-1238.

Yilmaz, S., Yazıcıoğlu, O., Saygın, S., Polat, N. (2013). Some reproduction properties of European perch (Perca fluviatilis L., 1758) population in Lake Ladik (Samsun, Turkey). The Black Sea Journal of Sciences, 3, 9, 34-46.

Zar, J.H. (1999): Biostatistical analysis. 4th Edition. PrenticeHall, New Jersey, USA. 663pp. 